Animals Inside Out

Natural History Museum, London.

Until 16 September 2012, then on tour.

Damien Hirst

Tate Modern, London.

Until 9 September 2012

cuvier), floats in its vitrine with skin like rumpled denim, misshapen fins and a gaping mouth revealing rounded, un-razor-like teeth. The iconic Mother and Child Divided (1993) features a cow and calf, each halved lengthways, hovering in four formalin-filled glass cases. The work bears a fleeting similarity to von Hagens' creations until you walk between the split carcasses. Instead of brilliant reds and purples, the wilted organs are a dull grey.

It is tempting to say that the British artist could learn a thing or two from the idiosyncratic German about preserving animals, but that would miss the point of these particular pieces: that death is ugly, awful, inevitable, and to doll it up is misguided.

In Hirst's hands death can also be beautiful. Butterfly wings have never been used to greater effect than in Doorways to the Kingdom of Heaven (2007), a triptych resembling a cathedral's stained-glass windows. In and Out of Love (1991) is a bright, humid room filled with hundreds of fluttering butterflies. As I watch, one seems dead, until a museum employee picks it up and lays it in a bowl of cut-up fruit. It lives!

Hirst isn't all about animals. Pills, cigarettes and jewels are major motifs in his art, and the exhibition's chronological presentation traces how his use of these objects has evolved. A single cabinet of pharmaceuticals and surgical equipment (Sinner, 1988) morphs into a room-sized pharmacopoeia (Pharmacy) four years later. By 2000, Trinity - Pharmacology, Physiology, Pathology is a room jammed with cabinets of gleaming silver surgical equipment, drug packaging and anatomy models.

But, a science-minded reader might ask, is it art? Here, intention and context are everything. Hirst's animals and objects are art because he says they are, and galleries such as the Tate Modern agree. Von Hagens, who purposefully chose the NHM as his venue, summed up his position in a 2007 interview: "I don't do Damien Hirst," he said. "I am an anatomist, not an artist.” Von Hagens' dead animals look prettier than most of Hirst's, but that is the point.

Ewen Callaway is a news reporter for Nature in London.

\title{
FICTION
}

\section{New moral arbiters}

\section{Jennifer Rohn enjoys an epic novel about scientists, the media, ethics and society.}

$\int$ ames Meek's novel about scientists and society, The Heart Broke In, tackles a big question: what does the rise of secularism in much of the West mean for ethical codes?

Some stories might suggest that rationalism should provide some kind of model. But Meek uses nuanced debate to build towards a very different climax. His mouthpieces are $\mathrm{Bec}$, a malaria researcher; her computationalbiologist lover, Alex; Bec's misbehaving exrock-star brother, Ritchie; and their friends, family and lovers. Meek, a former science correspondent for The Guardian newspaper, deftly handles the complex, day-to-day issues that scientists grapple with: the ethics of research; interaction with society; lab politics; and the struggle to make a mark in a difficult profession. The Heart Broke In is a realistic slice of life at the bench, reflecting both the admirable and the unflattering qualities of scientists.

Meek uses Alex's Uncle Harry, a militant atheist and famous cancer researcher, to explore whether science can replace God. Harry boasts of besting God by saving lives with his niche cure for one rare form of cancer, but develops a different type of tumour himself. Science can neither save him nor help him to accept the end of his existence.

In another plot

In the absence of a viable moral code, good and bad are enforced by naming and shaming in the press.

strand, Bec romantically spurns Val, a militant Christian and the editor of a prominent newspaper. Val labels her an intellectual obsessive cut off from ordinary life, and tries to exact revenge by destroying her public reputation using the media weapons at his disposal.

Somewhere in the middle, Bec and Alex flounder. Bec is so devoted to her science that she allows herself to be parasitized by an African worm to study its protective effects against malaria. Alex is a dreamer whose hyped Nature paper on a 'treatment' for ageing ("SCIENTIST FINDS FOUNTAIN OF YOUTH!", shrills the headline in Val's paper) transforms him into an unproductive media darling. In danger of becoming a onehit wonder like Harry, Alex starts to realize that this might be the normal progression of a 'successful' scientific career - a suspicion confirmed when he interviews the brightest minds in his field for a documentary. All typecast by one big breakthrough, they have spent the rest of their lives trying to recapture the glory, to little avail.

As their personal problems mount, the scientists emerge as refreshingly threedimensional in a way rarely seen in fiction. Yet Meek also plays with the one-dimen-

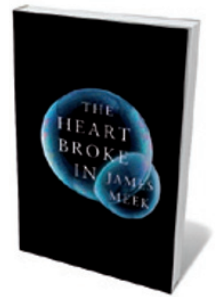

The Heart Broke In JAMES MEEK Canongate/ Farrar, Straus and Giroux: 2012. 551 pp./416 pp. $£ 17.99 / \$ 28$ sional view of scientists so often taken by the media.

Val, for instance, sees scientists as arrogant, atheistic meddlers. Ritchie is conflicted: expressing surprise that scientists could actually be well dressed or have friends, while also holding up Bec and Alex as the paragons he will never be. Then, when the pair grow more famous than he is, he describes them sarcastically as white-coated secular saints. Bec's mother, meanwhile, fears her daughter's disapproval of her bizarre diets, and marvels that scientists get anywhere when they are "closed to new ideas".

Even the scientists flirt with stereotypes. $\mathrm{Bec}$, for instance, berates herself because she can't recall how many times she had sex with Val - the kind of thing, she feels, that a scientist should be able to monitor. And Harry regales the young Alex with mythical descriptions of his work, from battles and breakthroughs to silver bullets and holy grails. Part of Alex's growth as a character is realizing that his profession isn't nearly as heroic as Harry makes out.

The Heart Broke In ends with almost everyone receiving their comeuppance. In the absence of a viable moral code, good and bad are enforced by naming and shaming in the press and social media - not by the desire to do no wrong, but by the imperative not to get caught. Science and religion have had their day, it says: the media, old and new, are the higher powers, with the ability to create and destroy reputations in predictable cycles.

Jennifer Rohn is a cell biologist at University College London and the editor of LabLit.com Her most recent novel is The Honest Look. e-mail:jenny@lablit.com 